\title{
Opsoclonus myoclonus ataxia may differentiate postinfectious autoimmune encephalitis from infectious encephalitis
}

\author{
Seong-Joon Lee ${ }^{1} \mathbb{1} \cdot \operatorname{In} \mathrm{Ja} \mathrm{Shin}^{1} \cdot \mathrm{Tae}^{-J o o n} \mathrm{Kim}^{1}$
}

Received: 11 June 2021 / Accepted: 22 September 2021 / Published online: 29 September 2021

(c) The Author(s) 2021

\section{Dear Editor,}

We report a patient who could be diagnosed as autoimmune postinfectious encephalitis due to occurrence of opsoclonus myoclonus ataxia syndrome (OMS) while initially treated under the impression of herpes simplex virus (HSV) encephalitis.

A 19-year-old male presented with 4 days of fever, headache, and nausea. Upon clinical examination, meningeal irritation sign was positive without focal neurological deficits. Cerebrospinal fluid (CSF) study showed elevated opening pressure, white blood cell count of 130 (lymphocyte $86 \%$ ), elevated protein of $154 \mathrm{mg} / \mathrm{dL}$, and glucose of $50 \mathrm{mg} / \mathrm{dL}$. Brain magnetic resonance imaging (MRI) showed T2 hyperintensities and swelling of bilateral medial temporal lobes (Fig. 1A). Serologic test for HSV IgM was equivocal, while Mycoplasma pneumoniae $\operatorname{IgM}$ was positive (titer 2.6 [0.0-0.8]). CSF HSV PCR was negative (Table 1). Under the impression of HSV meningoencephalitis, IV acyclovir and oral doxycycline was started. On HOD2 patient developed diplopia, downbeat, and torsional nystagmus. Over the next few days, the patient was neurologically stable, but fever did not subside. The patient deteriorated on HOD 6 with fluctuating right ptosis and esotropia. Intermittent bouts of uncontrolled multivectorial rapid eye movements which could be classified as opsoclonus occurred (Fig. 2, Video) with truncal ataxia and limb dysmetria. The frequency of opsoclonus was $6 \sim 8 \mathrm{~Hz}$, with an amplitude of $5 \sim 10$ degrees, and was provoked by initiation of saccades. The patient also complained of

Seong-Joon Lee

editisan@gmail.com

1 Department of Neurology, Ajou University School of Medicine, Ajou University Medical Center, 164, World cup-ro, Yeongtong-gu, Suwon, Gyeonggi-do 16499, Republic of Korea confusion and vivid dreams. Under the syndromatic diagnosis of OMS, postinfectious etiology was suspected, and IV steroid therapy was started. The results of paraneoplastic antibodies and autoimmune synaptic antibodies were negative. There was partial response to steroids, but the patient complained of urinary retention. Brain MRI on HOD12 revealed patchy T2 high signal intensities in cerebellar dentate nucleus, bilateral thalamus, and basal ganglia (Fig. 1A). Spinal MRI revealed signal changes in T1-4 and T4-T12 levels (Fig. 1B). The patient further underwent 5 cycles of plasma exchange with excellent clinical response. Serologic exam at HOD17 showed negative conversion of HSV IgM and positive HSV IgG. Mycoplasma pneumoniae IgM also showed negative conversion, with positive Mycoplasma pneumoniae IgG (>100AU/mL [0.0-11.9]). The patient was able to be discharged home at HOD24 and has not shown recurrence for over 6 months.

The causes of OMS in adults include paraneoplastic, parainfectious, toxic-metabolic, and idiopathic etiologies, while the pathophysiology is thought to be immunological [7]. Reported parainfectious cases are associated with HIV, Mycoplasma pneumoniae, and Salmonella, among others [7]. On the contrary, neuro-ophthalmologic presentation in HSV encephalitis, other than cranial nerve signs, due to increased intracranial pressure, is rare [2, 8]. Based on such factors, the development of OMS led us to suspect an underlying autoimmune mechanism.

The preceding infection may have been HSV meningoencephalitis, or Mycoplasma pneumoniae infection. Reported clinical picture of post HSV autoimmune encephalitis is somewhat different from this patient [1], with longer days from initial encephalitis to relapsing autoimmune encephalitis, and neuropsychiatric presentations. Typical enhancing frontotemporal T2 hyperintensities and positive NMDA receptor antibodies were also not seen in this patient. 


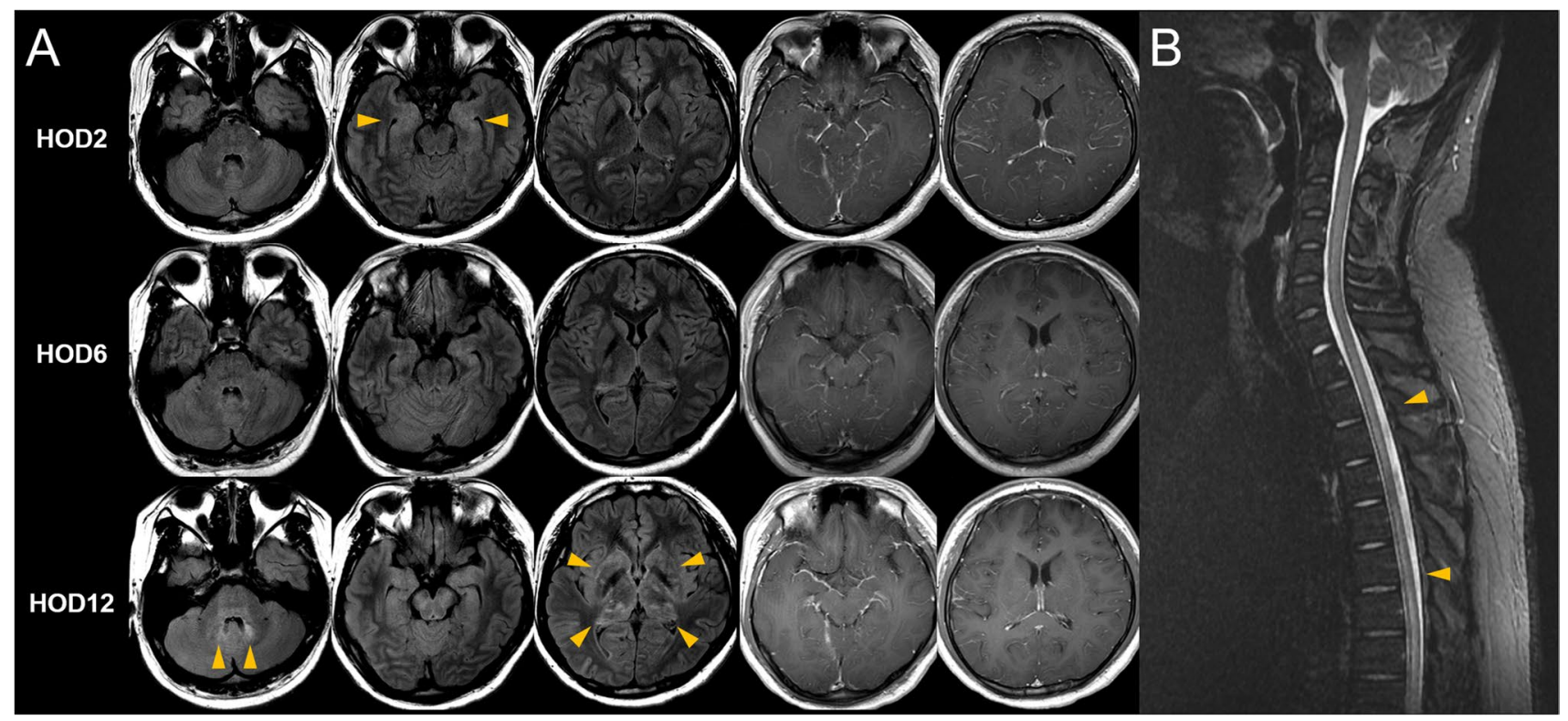

Fig. 1 The brain and spinal MRI findings. A On HOD2, swelling and T2 high signal intensity are seen at bilateral medial temporal lobes, raising clinical suspicion of herpes simplex encephalitis. The patient deteriorated on HOD6, but no new brain lesions are seen. Brain MRI performed at HOD12 shows T2 hyperintensities at cer-

Neurological manifestations of Mycoplasma infections occur through three major mechanisms, direct neuronal damage, vascular occlusion type pathology, and indirect autoimmunity [5]. Immune pathogenesis is usually suggested in cases of OMS associated with Mycoplasma pneumoniae [3, 4, 6]. ebellar dentate nucleus, bilateral thalamus, and basal ganglia. B T2 hyperintensities in T1-4 and T4-T12 levels are also seen in spinal MRI taken at HOD12. MRI, magnetic resonance imaging; HOD, hospital day

Characteristic bilateral MRI lesions are reported, involving the pons, thalamus, basal ganglia, brainstem, or splenium, and there is evidence that both vascular occlusive pathology and indirect autoimmune mechanisms are responsible [5]. While we can not reach a conclusion to the underlying infectious pathogen, this case highlights that prompt recognition 
Table 1 Results of serologic and cerebrospinal fluid exams for diagnosis of the encephalitis

\begin{tabular}{|c|c|c|c|c|c|c|}
\hline & HOD 1 & HOD 6 & HOD 8 & HOD 13 & HOD 15 & HOD 17 \\
\hline \multicolumn{7}{|l|}{ Serum tests } \\
\hline CMV IgM & Negative & & & & & \\
\hline HSV IgM & Equivocal & & & & & Negative \\
\hline HSV IgG & & & & & & Positive \\
\hline VZV IgM & Negative & & & & & Negative \\
\hline M. pneumonia IgM & Positive $2.6(0.0-0.8)$ & & & & & Negative \\
\hline M. pneumoniae $\mathrm{IgG}$ & & & & & & $\begin{array}{l}\text { Posi- } \\
\quad \text { tive }>100 \mathrm{AU} / \\
\mathrm{mL}(0.0-11.9)\end{array}$ \\
\hline
\end{tabular}

$\begin{array}{ll}\text { Anti-HIV I/II } & \text { Negative } \\ \text { VDRL } & \text { Negative }\end{array}$

Paraneoplastic antibody*

Autoimmune synaptic encephalitis $\mathrm{Ab} \dagger$

GAD II Ab

Aquaporin $4 \mathrm{IgG}$

Negative

GD1b Ab, IgM

GQ1b Ab

MOG Ab

Cerebrospinal fluid

HSV type I PCR

HSV type II PCR

HSV RT PCR

VZV PCR

Enterovirus RT PCR

EBV PCR

HHV 6 PSR

Polyoma Virus PCR

M. pneumoniae $\mathrm{PCR}$

JBE virus RT PCR

CMB RT PCR

TB PCR hybridization

VDRL

$\begin{array}{llll}\text { Negative } & \text { Negative } & \text { Negative } & \text { Negative } \\ \text { Negative } & \text { Negative } & \text { Negative } & \text { Negative } \\ \text { Negative } & \text { Negative } & \text { Negative } & \text { Negative } \\ \text { Negative } & \text { Negative } & \text { Negative } & \text { Negative } \\ \text { Negative } & & \\ & & \text { Negative } \\ & & \text { Negative } \\ & & \text { Negative } \\ & & \text { Negative } \\ & & \text { Negative } \\ & & \text { Negative }\end{array}$

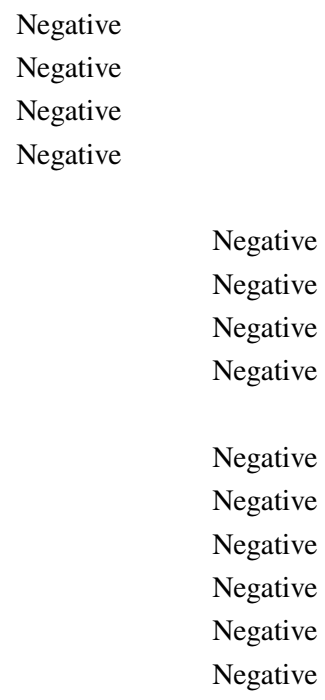

Negative

*Paraneoplastic antibody testing was performed for anti-Hu autoantibody, anti-Ri autoantibody, anti-Yo autoantibody, anti-amphiphysin autoantibody, anti-CV2 autoantibody, anti-PNMA (Ma2/Ta) autoantibody, anti-recoverin autoantibody, anti-SOX1 autoantibody, and anti-titin (MGT30) autoantibody

Autoimmune synaptic encephalitis antibody was performed for anti-NMDA receptor antibody, anti-LGI1antibody, anti-CASPR2 antibody, antiAMPA receptor antibody, anti-DPPX antibody, and anti-GABA-B receptor antibody

$C M V$ cytomegalovirus, $H S V$ herpes simplex virus, $H I V$ human immunodeficiency virus, VDRL Venereal Disease Research Laboratory, GAD glutamic acid decarboxylase, $M O G$ myelin oligodendrocyte glycoprotein, $V Z V$ Varicella zoster virus, $P C R$ polymerase chain reaction, $R T P C R$ real-time polymerase chain reaction, $E B V$ Epstein-Barr virus, $H H V$ human herpes virus, JBE Japanese B encephalitis, TB Mycobacterium tuberculosis 


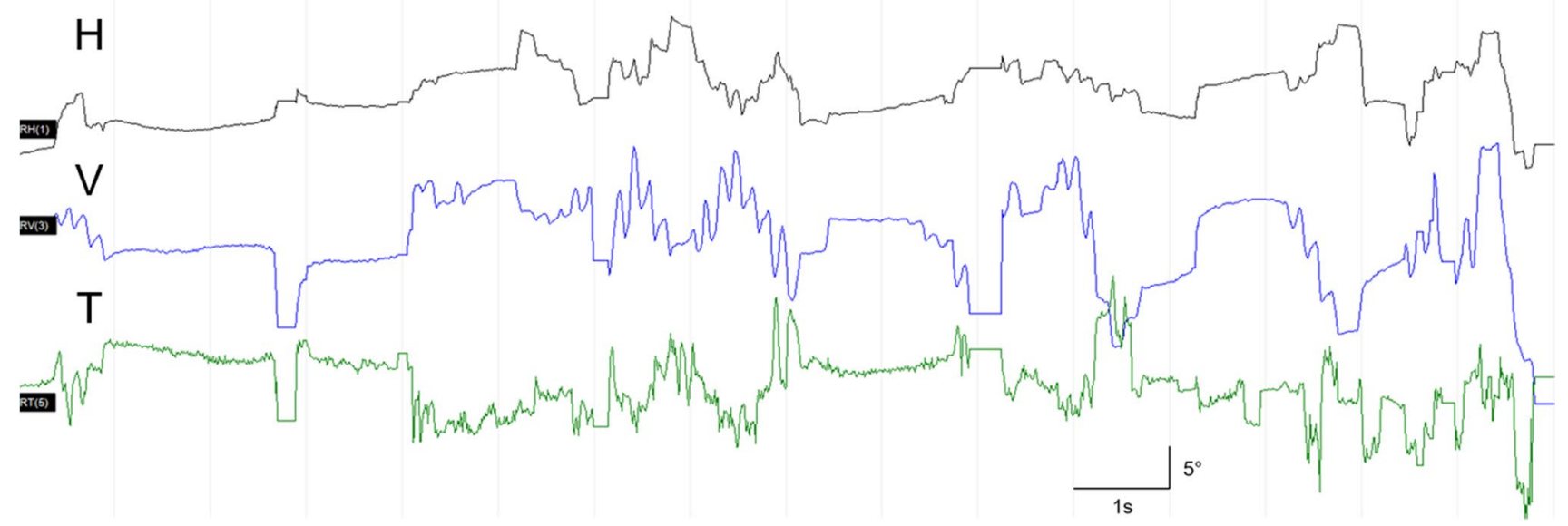

Fig. 2 VNG findings showing opsoclonus. VNG (SLVNG, SLMED, Seoul, South Korea) shows intermittent bouts of fast involuntary spindle shaped multivectorial saccadic oscillations without intersaccadic interval. VNG, video nystagmography

of OMS and immunomodulatory treatment can bring excellent outcomes.

Supplementary Information The online version contains supplementary material available at https://doi.org/10.1007/s10072-021-05632-1.

Funding This work was supported by the New Faculty Research Fund of Ajou University School of Medicine (M-2020-C0460-00067).

\section{Declarations}

Informed consent Not applicable.

Ethical approval This study followed the tenets of the Declaration of Helsinki and was performed according to the guidelines of Institutional Review Board of Ajou University Hospital.

Conflict of interest The authors declare no competing interests.

Open Access This article is licensed under a Creative Commons Attribution 4.0 International License, which permits use, sharing, adaptation, distribution and reproduction in any medium or format, as long as you give appropriate credit to the original author(s) and the source, provide a link to the Creative Commons licence, and indicate if changes were made. The images or other third party material in this article are included in the article's Creative Commons licence, unless indicated otherwise in a credit line to the material. If material is not included in the article's Creative Commons licence and your intended use is not permitted by statutory regulation or exceeds the permitted use, you will need to obtain permission directly from the copyright holder. To view a copy of this licence, visit http://creativecommons.org/licenses/by/4.0/.
Munoz-Cabello B, Torres-Torres C, Llufriu S, Gonzalez-Gutierrez-Solana L, Gonzalez G, Casado-Naranjo I, Rosenfeld M, Graus F, Dalmau J, Spanish Prospective Multicentric Study of Autoimmunity in Herpes Simplex E (2015) Autoimmune postherpes simplex encephalitis of adults and teenagers. Neurology 85:1736-1743

2. Ballaekere JS, Chebbi PP, Sundarmurthy H, Parameshwarappa A (2014) Weber syndrome: herpes simplex virus brainstem encephalitis as an etiology. Am J Med 127:e5-6

3. Huber BM, Strozzi S, Steinlin M, Aebi C, Fluri S (2010) Mycoplasma pneumoniae associated opsoclonus-myoclonus syndrome in three cases. Eur J Pediatr 169:441-445

4. Mesraoua B, Abbas M, D'Souza A, Miyares FR, Hashem M, Osman Y, Deleu D (2011) Adult opsoclonus-myoclonus syndrome following Mycoplasma pneumoniae infection with dramatic response to plasmapheresis. Acta Neurol Belg 111:136-138

5. Narita M (2016) Classification of extrapulmonary manifestations due to mycoplasma pneumoniae infection on the basis of possible pathogenesis. Front Microbiol 7:23

6. Nunes JC, Bruscato AM, Walz R, Lin K (2011) Opsoclonusmyoclonus syndrome associated with Mycoplasma pneumoniae infection in an elderly patient. J Neurol Sci 305:147-148

7. Oh SY, Kim JS, Dieterich M (2019) Update on opsoclonus-myoclonus syndrome in adults. J Neurol 266:1541-1548

8. Shaikh AG, Termsarasab P, Riley DE, Katirji B (2013) The floccular syndrome in herpes simplex type 1 encephalitis. J Neurol Sci 325:154-155

Publisher's note Springer Nature remains neutral with regard to jurisdictional claims in published maps and institutional affiliations.

\section{References}

1. Armangue T, Moris G, Cantarin-Extremera V, Conde CE, Rostasy K, Erro ME, Portilla-Cuenca JC, Turon-Vinas E, Malaga I, 